\title{
Public Perceptions of Legislative Action to Reduce Plastic Pollution: A Case Study of Atlantic Canada
}

\author{
Shen Molloy ${ }^{1}$, Andrew S. Medeiros ${ }^{1}$, Tony R. Walker ${ }^{1, * \mathbb{D}}$ and Sarah J. Saunders ${ }^{2}$ \\ 1 School for Resource and Environmental Studies, Dalhousie University, Halifax, NS B3H 4R2, Canada; \\ sp902685@dal.ca (S.M.); andrew.medeiros@dal.ca (A.S.M.) \\ 2 World Wildlife Fund Canada, Halifax, NS B3J 1P3, Canada; ssaunders@wwfcanada.org \\ * Correspondence: trwalker@dal.ca
}

Citation: Molloy, S.; Medeiros, A.S. Walker, T.R.; Saunders, S.J. Public Perceptions of Legislative Action to Reduce Plastic Pollution: A Case Study of Atlantic Canada. Sustainability 2022, 14, 1852. https:// doi.org/10.3390/su14031852

Academic Editors: Qamar Schuyler and Britta Denise Hardesty

Received: 15 December 2021

Accepted: 2 February 2022

Published: 6 February 2022

Publisher's Note: MDPI stays neutral with regard to jurisdictional claims in published maps and institutional affiliations.

Copyright: (C) 2022 by the authors. Licensee MDPI, Basel, Switzerland. This article is an open access article distributed under the terms and conditions of the Creative Commons Attribution (CC BY) license (https:// creativecommons.org/licenses/by/ $4.0 /)$.

\begin{abstract}
Government-led legislation is a key strategy to reduce plastic pollution; however, societal perception can heavily influence government intervention for environmental issues. To understand the public acceptability of government action to reduce plastic pollution, we examine the perception of existing and upcoming legislative action on single-use plastics (SUPs) by means of a structured survey with additional semi-structured interviews. Our focus is on the four Atlantic provinces of Canada, which was the first region in Canada to implement provincial-wide legislation for plastic reduction at the consumer level in 2019. Results show strong public support $(77 \%, \mathrm{n}=838)$ for bans of SUP bags at the consumer level, and for further plastic pollution reduction legislation. However, the level of support differed between regions and by demographics. Semi-structured interviews show that decision makers should increase efforts in raising consumer awareness and standardizing regulations across jurisdictions for smoother transitions prior to legislative action.
\end{abstract}

Keywords: single-use plastics (SUPs); plastic pollution management; policy; pollution; Atlantic Canada

\section{Introduction}

Plastic pollution is gaining recognition among the public as a global contaminant that requires government intervention. Since mass production in the 1950s, plastic and plastic products have become heavily integrated into modern society [1,2]. Overproduction, societal consumption, and mismanagement of plastic waste increase the likelihood of plastic leakage into the environment [3-5]. As plastic pollution is progressively becoming a mainstream concern for the public, a global movement has motivated government legislative intervention, through bans and other forms of regulation, to reduce plastic use and disposal [6-9]. Public support is a key component to ensuring the compliance and acceptance of legislation to control plastic pollution [10,11]. As such, understanding public perceptions is a critical component in directing future plastic reduction legislation, especially since plastic production has doubled every decade, driven largely by single-use plastic (SUP) consumer items [4].

Since commercial production began, Canada has produced approximately 4.6 million tons of plastic, yet 2.8 million tons is now plastic waste [12]. Plastics are now used in every sector of the Canadian economy [13-16], which produces more plastic waste per capita than anywhere else in the world; yet only $9 \%$ of this plastic is properly recycled [17-19]. The Government of Canada has increased efforts in achieving zero plastic waste by committing to legislatively ban check-out bags, straws, stir sticks, six-pack rings, plastic cutlery, and food containers made from hard to recycle plastics under Schedule 1 of the Canadian Environmental Protection Act (CEPA) 1999 by the end of 2021 [19-22]. However, due to challenges arising from the COVID-19 pandemic with public concerns over food safety and virus transmission [14], combined with litigation from the plastics industry, the federal government has delayed this ban until the end of 2022 [22]. 
Several jurisdictions across Canada have either implemented or are considering legislation to reduce plastic waste, specifically SUP bags [14-16]. This is in part due to low national and provincial recycling rates [9] and increasing public awareness about plastic pollution $[14,16]$. Globally, legislation to ban SUP bags and other SUP items has increased rapidly in recent years due to increasing public awareness and concerns over societal consumption and environmental impacts of mismanaged plastic waste [7,8]. Xanthos and Walker [7] conducted a global inventory of policies to ban or tax plastic bags. Their review reported that many jurisdictions around had implemented policies to ban or tax plastic bags, beginning in 1991 [7]. However, Schnurr et al. [8] reported that the dramatic rise in plastic bag reduction policies began to extend to other SUP items such as straws, stir sticks, and plastic cutlery and included both national and sub-national regulations.

On a provincial level, each province in Atlantic Canada is following their own regulatory regime for plastic pollution legislation. Prince Edward Island was the first Canadian province to implement a province-wide plastic bag ban on 1 July 2019, closely followed by Newfoundland and Labrador on 1 October 2020, and Nova Scotia on 30 October 2020. New Brunswick has no current plans for province-wide legislation of plastic bags or other SUPs; however, there are ongoing efforts at the municipal level to reduce plastic bags $[14,16,23]$.

The current difference in legislation between Atlantic provinces offers a unique opportunity to observe the public's perceptions of plastic pollution legislation before, during, and after legislation has been implemented. As such, we seek to understand whether location, demographics, and/or existing concern for the impacts of plastics on the environment influences public support for the upcoming and/or existing legislation on SUPs in Atlantic Canada. Although public compliance of proposed government legislation is anticipated based on previous national Canadian surveys by Kitz et al. [14] and Walker et al. [16], there may still be potential negative public perceptions arising from government action which this study attempted to gauge.

This study further attempts to identify best practices for future SUP mitigation strategies in Atlantic Canada to progress SUP reduction efforts by (1) identifying strategies for improving public cooperation of SUP reduction initiatives; (2) providing future direction for SUP legislation; and (3) better influencing SUP education and communication materials to the public. These outcomes can inform future policy and legislation decisions, as they advance the knowledge gap that exists around public perceptions of plastic reduction legislation.

\section{Materials and Methods}

We adapted methodology from Varkey et al. [15] and used surveys and subsequent semi-structured qualitative interviews to understand public perception of plastic reduction legislation in the Atlantic provinces of Canada. A survey was conducted through online distribution to reach residents of Atlantic Canada to gauge interest and concerns surrounding SUPs, and to determine perceptions of plastic bag bans. Semi-structured interviews were conducted to provide an in-depth comparison of SUP reduction between provinces from experts in the field. We note that our research was conducted prior to enactment of plastic bag bans in Newfoundland and Labrador and Nova Scotia during summer 2020. Data collection methods were completed in accordance with the Dalhousie University Research Ethics Board.

\subsection{Survey}

A survey was tailored to each Atlantic province to accommodate temporal variation in implementation of SUP reduction legislation (see Appendix A.1). For example, at the time of the survey (June to August 2020), only Prince Edward Island had already implemented regulations, whereas others were proposed (Nova Scotia and Newfoundland and Labrador) or were not planned (New Brunswick). Each survey began with a brief section on respondent demographics, followed by 10-12 multiple choice questions (depending on province) related to their use of plastic bags and perceptions of plastic pollution legislation in their 
respective province. The survey was anonymous, and respondents had the freedom to leave the survey at any time. Only completed surveys were considered for analysis. Survey respondents also had the option to add additional comments at the end of the survey. There was no incentive or compensation provided for completing the survey. The survey was first distributed online in June 2020 via social media (e.g., Facebook, Instagram, and Twitter), and remained open until the end of August 2020. Since the survey was released online, it was not possible to determine the number of people the survey reached. The survey was also promoted on local news outlets through radio interviews and web articles in New Brunswick, Nova Scotia and Prince Edward Island, increasing exposure to thousands of potential participants across a range of populations. Example survey questions tailored for Nova Scotia are shown in Table 1.

Table 1. Example survey questions tailored for Nova Scotia.

\section{Survey Questions}

1. Are you concerned about the impacts of plastic bags on the environment?

2. How often do you see plastic bags in the environment?

3. How often do you use plastic bags?

\section{Possible Responses}

Yes/No, Why?
Every day/A few times a week/About once a week/A few times a month/Once a month/Less than once a month.

4. How do you dispose of plastic bags?

Always/Frequently (1-2 times a week)/Sometimes (1-2 times a month)/Rarely (only when I forget my reusable)/Never.

5 . How many reusable bags do you own? Garbage/Recycle/Reuse plastic bags at home/Other.

6. Do you know that a plastic bag ban is coming to force this year?

None/1-3/3-5/6+.

Yes/No.

7. Do you support or oppose the plastic bag ban? Support/Oppose/Unsure/No preference.

8. Will the plastic bag ban reduce your use of other single-use plastics such as straws, plastic to-go containers or take out coffee cups?

Yes/No/Unsure.

9. Would you prefer to pay an additional fee for a plastic bag as opposed to a having plastic bag ban?

Yes/No/Depends on how much the fee was/No preference.

10. Do you think more legislation to reduce plastic pollution should be implemented in your province?

Yes, If so, what would you like to see legislation banning?/No/No preference.

11. Has your use of single-use plastics increased because of COVID-19?

Yes/No/Unsure.

12. Do you have any additional comments about reducing single-use plastics or the plastic bag ban in your province?

Results of the survey were compiled in an Excel spreadsheet and responses for location, demographics, and existing concern for plastic pollution were extracted. Responses from the three factors were then individually compared against the corresponding responses of whether the participant supported, opposed, or was neutral about legislative action on SUPs. For each factor, responses for each level of support option were counted and standardized for comparison. The original count was converted into percentage of each response to highlight trends within the data. Using Excel Data Analysis, a one-way ANOVA was completed to compare responses within each of the three factors against the participants viewpoint on a bag ban. Factors were analysed individually to identify practical trends for future SUP reduction efforts. Following this, a Tukey-Kramer Ad Hoc test was conducted to identify groups that were different; $p<0.05$ was considered statistically significant. 


\subsection{Semi-Structured Interviews}

Semi-structured interviews were conducted concurrently with the distribution of surveys between June 2020 and August 2020. The interviews provided an in-depth comparison of the provinces' concerns and opinions from experts in the field. Interview participants included those who work in waste management, the environmental non-governmental organization (ENGO) sector, local or provincial government, and academic researchers in the four Atlantic provinces. As with the survey, interview questions were tailored to each province to accommodate temporal variation in implementation of SUP reduction legislation (see Appendix A.2). Interviews were semi-structured in nature and designed to gather a better understanding of the interviewee's ideas and concerns surrounding plastic legislation and best practices towards a zero plastic waste future for Atlantic Canada. Interviews were conducted using either video conference or phone call, which were recorded and transcribed. Participants' identities were kept anonymous using an alphanumeric code. Eight example semi-structured interview questions tailored for Nova Scotia are shown in Table 2.

Table 2. Eight example semi-structured interview questions tailored for Nova Scotia.

\section{Semi-Structured Interview Questions}

1. How does your work relate to single-use plastics?

2. What is your reaction to the recent announcement by the Canadian federal government to ban single-use plastics as soon as 2021?

3. Have you noticed a change in the amount of plastic pollution in your province over the last 5 years?

4. How do you think the general public will respond to the upcoming plastic bag ban? And do you have any ideas on how to make sure implementation is successful?

5. Do you think the plastic bag ban will also reduce people's use of other single-use plastics such as straws, plastic to-go containers or take out coffee cups?

6. Do you think more legislation to reduce plastic pollution should be implemented in your province? If so, what would you like to see legislation banning?

7. What is something you wish people knew about single-use plastics?

8. Do you have any other comments about reducing single-use plastics or the plastic bag ban in your province?

Note: Question \#2: Since this study was conducted, the Canadian federal government has since delayed the ban on SUPs by the end of 2022 [22].

Responses that addressed the three research questions were extracted from the transcript and analysed by the primary author through a process of theoretical thematic analysis as outlined by Maguire and Delahunt (2017) using an Excel spreadsheet [24]. The data were organized by question and conveyed as columns of all the comments from the participants. Each individual cell was then reviewed, and the comment was assigned as either a supportive, oppositional, or neutral comment. The data were then compared with the results from the survey to develop recommendations for future SUP reduction strategies.

\section{Results}

\subsection{Survey}

A total of 1,092 community members participated in the survey (712 from Nova Scotia, 231 from New Brunswick, 88 from Prince Edward Island, and 61 from Newfoundland and Labrador). Results showed differing levels of support for a provincial plastic bag ban between the four provinces. New Brunswick and Prince Edward Island were the most supportive provinces of the ban, both with $92 \%(n=211, n=81)$ of participants in support of a ban. Newfoundland and Labrador also displayed strong support, with $90 \%(n=55)$ approval for a plastic bag ban. There was more opposition in NS, with only $67 \%(n=491)$ 
of participants supporting a plastic bag ban (Figure 1). Overall, there was a high level of support $(77 \%, \mathrm{n}=838)$ for plastic bag bans across Atlantic Canada.

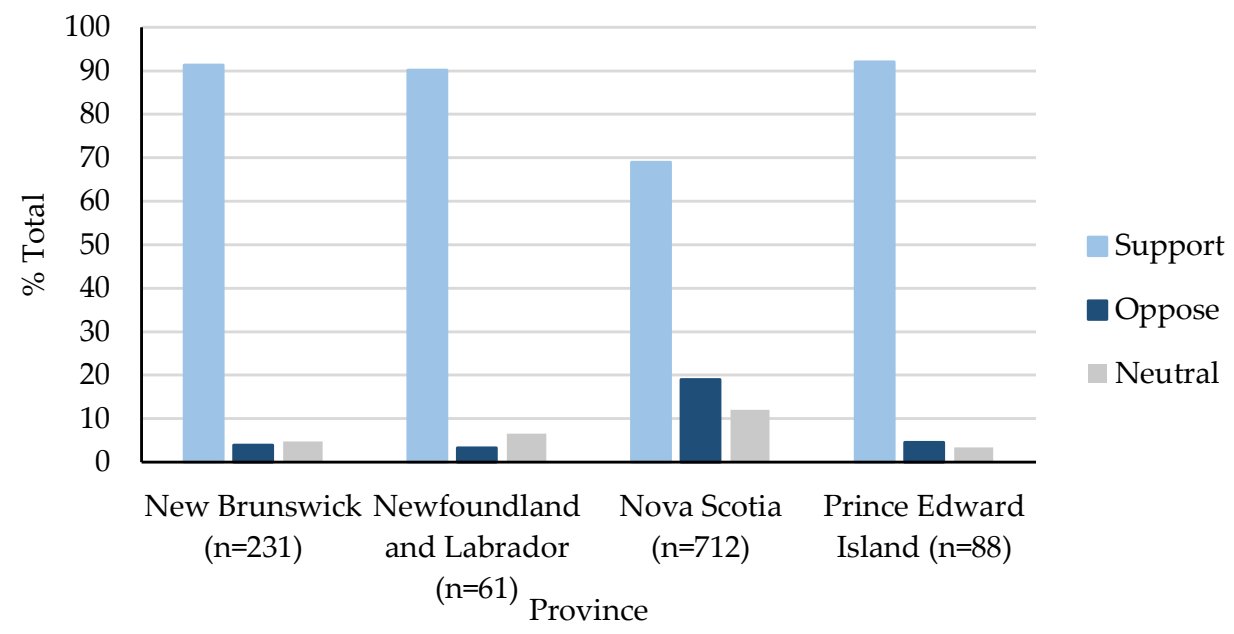

Figure 1. Survey responses of participants' perspectives on a plastic bag ban in Atlantic Canadian provinces.

When examining gender, 776 participants identified as female, whereas 293 identified as male. The survey shows $82 \%(n=639)$ of females supported a plastic bag ban compared to only $62 \%(\mathrm{n}=185)$ total support from males (Figure $2 \mathrm{a})$. Those who identify as nonbinary were included in our survey $(n=5)$; however, there was an insufficient number of responses to determine a trend. When examining the age category of respondents, 195 participants identified as 18-24, 208 participants identified as 25-34, the 35-44 and 45-54 age groups both had 140 participants, 172 participants identified as 55-66, and 238 participants identified as $65+$. Most age groups responded that they supported a plastic bag ban; however, the level of support varied across age categories. A total of $92 \%(n=180)$ of respondents aged 18-24 were strongly supportive, whereas only $63 \%(\mathrm{n}=152)$ aged $65+$ responded that they supported a ban. Support for a ban decreased with increasing age (Figure 2b).

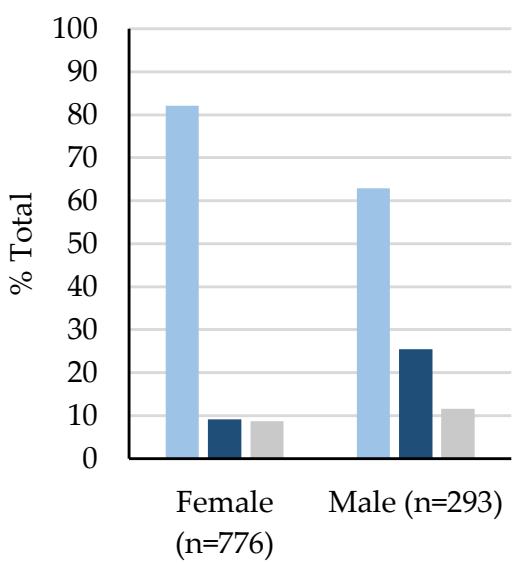

Gender

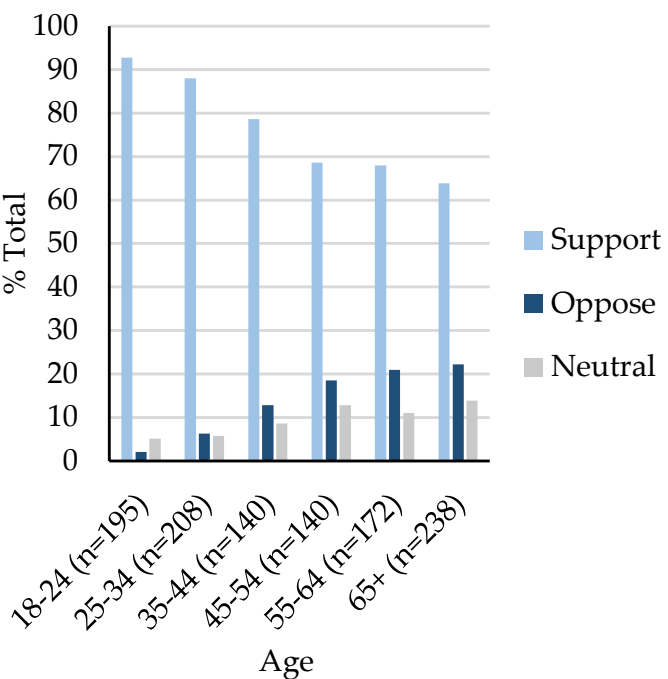

(b)

Figure 2. Survey responses of participants' perspectives on a plastic bag ban across Atlantic Canada, (a) relative to gender, and (b) relative to age. 
The survey suggests that having some form of advanced education results in a higher likelihood of a participant supporting a plastic bag ban. Those who identified as holding a bachelor's, master's, professional, or doctorate degree were the most supportive of a bag ban, with $82 \%(n=326), 89 \%(n=145), 85 \%(n=46)$, and $81 \%(n=40)$ in support, respectively. Following in succession, $76 \%(n=130)$ of participants with a college diploma, $65 \%(n=106)$ of participants with a high school diploma, $62 \%(n=10)$ of participants with an associate's degree, and $51 \%(n=29)$ of participants in the trades identified as supportive of a bag ban (Figure 3a). In terms of employment status, the survey showed that students were the most supportive, with $92 \%(n=108)$ of participants. This was followed by part-time workers with $87 \%$ in support $(n=71)$, unemployed participants with $83 \%$ $(n=52)$ in support, full-time workers with $78 \%(n=388)$ in support, retired participants with $66 \%(n=185)$ in support, and self-employed participants with $60 \%(n=34)$ in support of a plastic bag ban (Figure $3 b$ ).

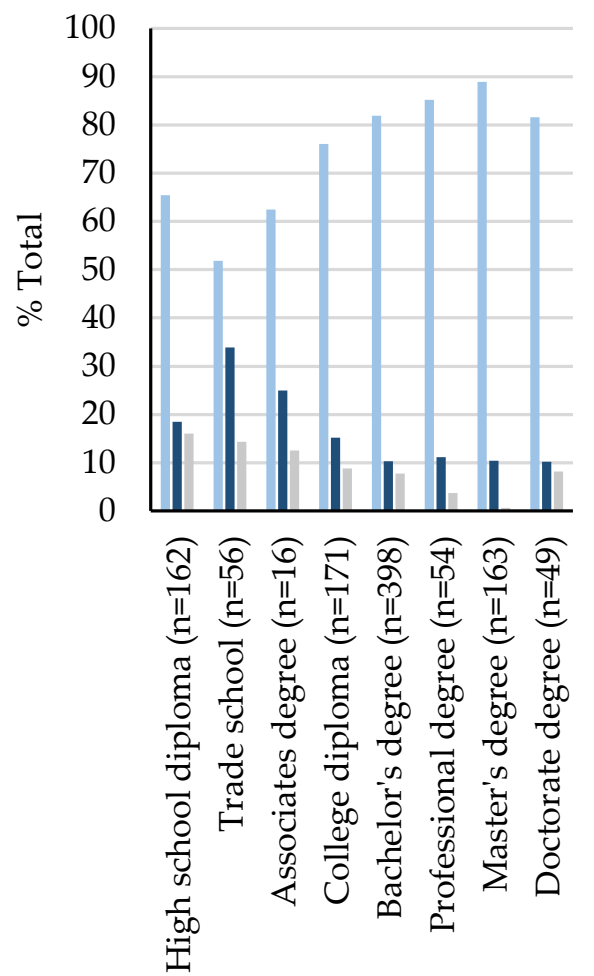

Education

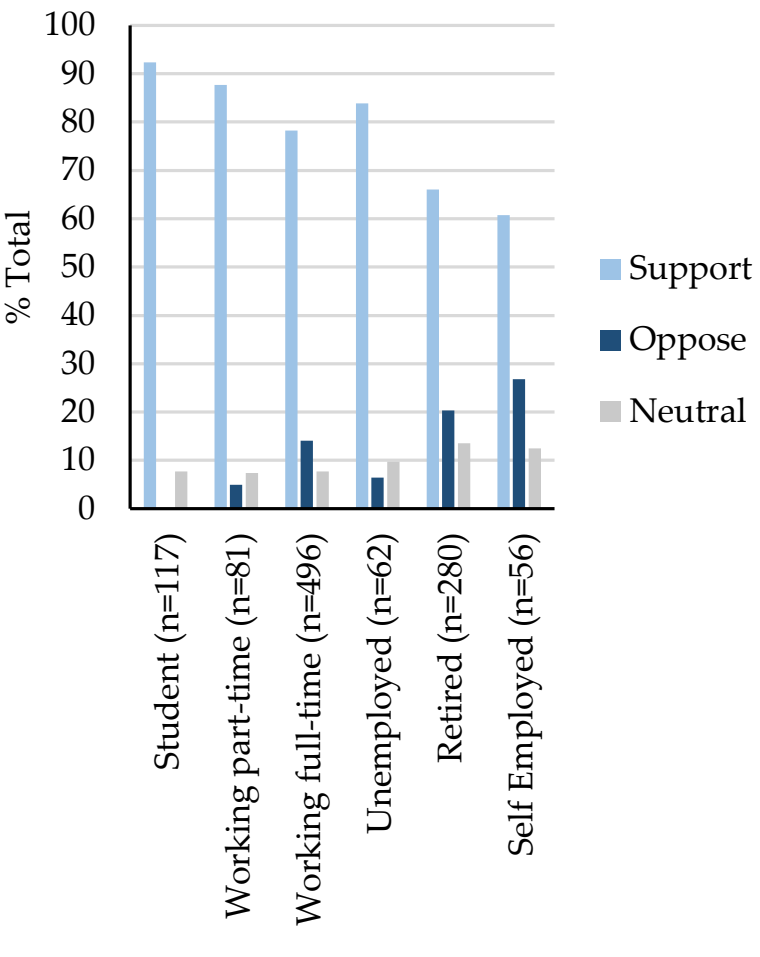

Employment

(a)

(b)

Figure 3. Survey responses of participants' perspectives on a plastic bag ban across Atlantic Canada, relative to (a) level of education, and (b) employment status.

Across Atlantic Canada, 1020 participants stated they were concerned about the impacts of plastics on the environment, whereas the remaining 70 participants were not. These responses were then compared with the participants' perception of a bag ban to determine if existing concern for the impacts of plastic bags had an influence on supportiveness of a bag ban. The survey shows $82 \%(n=837)$ of participants who are concerned about environmental impacts were supportive of a bag ban. Conversely, participants who identified that they were not concerned about environmental impacts of plastic pollution were largely unsupportive of a ban, with $88 \%(n=62)$ stating that they oppose a ban (Figure 4$)$. 


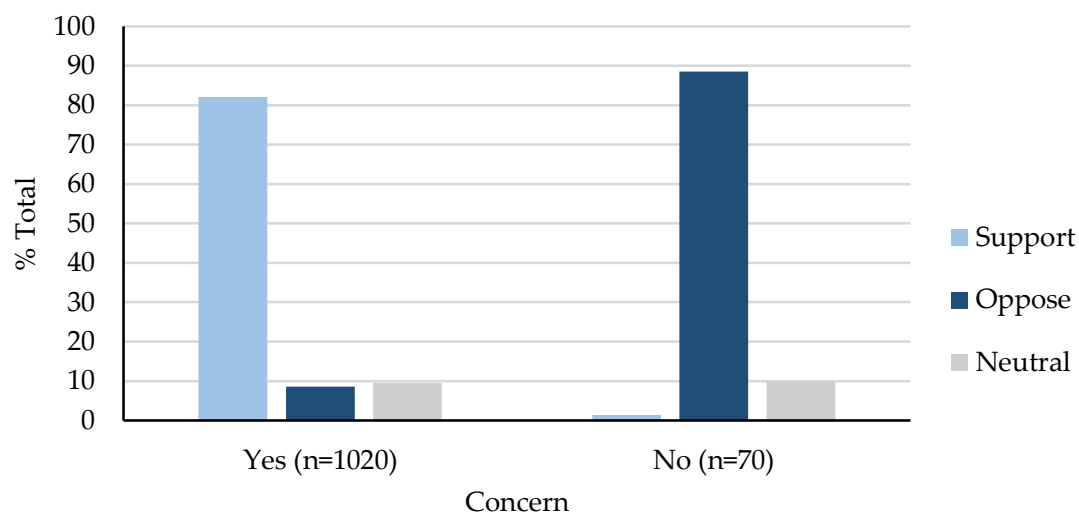

Figure 4. Survey responses of participants' perspectives on a plastic bag ban across Atlantic Canada relative to concern for the impacts of plastic bags on the environment.

When asked about future legislation, $75 \%(n=873)$ of respondents stated they would like to see more legislation reduce SUPs. New Brunswick was the province the highest support of respondents, with $92 \%(n=215)$ of participants expressing they would like to see further legislation for reducing single-use plastics. Respondents from Newfoundland and Labrador, Nova Scotia, and Prince Edward Island all had similar opinions about implementing further legislation to reduce SUPs in their province with $72 \%(n=43), 71 \%$ $(\mathrm{n}=516)$, and $71 \%(\mathrm{n}=63)$ in support, respectively (Figure 5). When provided with the opportunity to nominate other SUPs to be included in a bag ban under future legislation, common answers included straws, plastic bags, and plastic bottles.

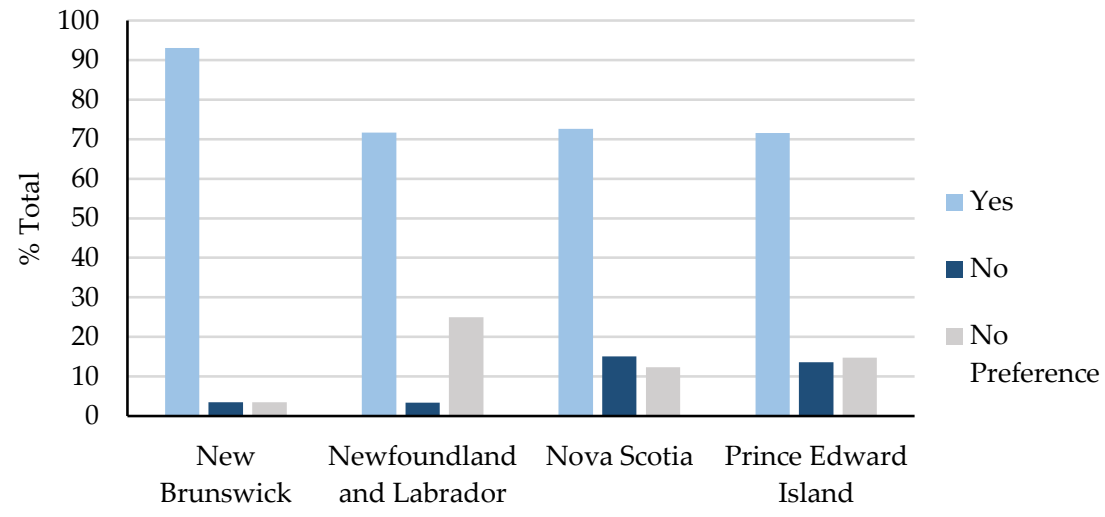

Province

Figure 5. Survey responses of participants' perspectives on a plastic bag ban across Atlantic Canada relative to desire for future plastic pollution legislation.

The analysis shows that most participants across Atlantic Canada have similar perceptions of a plastic bag ban; however, we found a significant difference between location (one-way ANOVA, $F=8.25, p=0.03$ ). There was also a significant difference between demographic categories within individual provinces, with differences in the level of education in Newfoundland and Labrador (one-way ANOVA, $F=15.85, p<0.01$ ), and age (one-way ANOVA, $F=11.48, p<0.01$ ) and employment status (one-way ANOVA, $F=12.24, p<0.01)$ in Prince Edward Island. ANOVA statistical results from the survey are shown in Appendix A.2 (see ANOVA Results Table A1). Within these factors, Nova Scotia was found to have statistically lower support for the ban than the other three Atlantic provinces. In Newfoundland and Labrador, those with a trades background were found to have statistically lower support than other levels of education. In Prince Edward Island, age groups with statistically lower support were 45-54, and 65+. Retired and self-employed participants also had statistically lower support than other employment cate- 
gories. Tukey-Kramer Post Hoc Test results are shown in Appendix A.2 (see Tukey-Kramer Post Hoc Test results Table A2).

\subsection{Semi-Structured Interviews}

Of the 36 interview requests sent to potential participants, 14 were available: six participants from New Brunswick, one participant from Newfoundland and Labrador, four participants from Nova Scotia, and three participants from Prince Edward Island. The final sector tally included four government workers (municipal or provincial), three employees from the ENGO sector, four academic researchers, and three waste managers. Interview questions which provoked responses that addressed the three research questions were threefold.

Reactions to the response of a plastic bag ban were mixed, highlighting the need for improved public cooperation. Participants from New Brunswick expressed uncertainty, stating that there are many unknowns due to lack of communication with the federal government and conflicting public support. Participants from the other three Atlantic provinces discussed a more positive response, with the most enthusiasm from those in Prince Edward Island. Across Atlantic Canada, government workers were apprehensive, although they understood the public desire for environmental action. ENGO (environmental non-governmental organization) workers were eager about a bag ban and optimistic about the potential for it to spark further eco-friendly behaviour. Academics were supportive, although some would like further education from the federal government prior to implementation. Waste managers were positive about a plastic bag ban, stating that it is something that should be well received (Table 3).

Table 3. Predictions of the public's response to a plastic bag ban organized by province and sector with sample quotes from interview participants.

\begin{tabular}{|c|c|c|}
\hline \multicolumn{3}{|c|}{ Question: How Do You Predict the General Public Will Respond to a Plastic Bag Ban? } \\
\hline \multicolumn{3}{|c|}{ New Brunswick } \\
\hline Government & $\begin{array}{l}\text { "It's a hard question right now with the unknowns of what's coming down from } \\
\text { CCME [Canadian Council of Ministers of the Environment] and the federal } \\
\text { government." }\end{array}$ & Neutral \\
\hline $\begin{array}{l}\text { ENGO (environmental } \\
\text { non-governmental } \\
\text { organization) }\end{array}$ & $\begin{array}{l}\text { "New Brunswick has the ability to make the shift. If the changes would be made, I } \\
\text { hope that people would react positively to it" }\end{array}$ & Support \\
\hline Academic research & $\begin{array}{l}\text { "Making the transition should not be too difficult...it might be a little tough to start } \\
\text { out with but it's coming in in a very user-friendly way." }\end{array}$ & Neutral \\
\hline Waste management & "I believe that it is something that can be a positive piece of change." & Support \\
\hline \multicolumn{3}{|c|}{ Newfoundland and Labrador } \\
\hline $\begin{array}{l}\text { ENGO (environmental } \\
\text { non-governmental } \\
\text { organization) }\end{array}$ & $\begin{array}{l}\text { "It seems to be accepted by a lot of people and expected almost, no one was shocked } \\
\text { to see it come in." }\end{array}$ & Support \\
\hline \multicolumn{3}{|c|}{ Nova Scotia } \\
\hline Government & $\begin{array}{l}\text { "There was a lot of interest from the public to see plastic bags banned ... but I'm not } \\
\text { sure where Covid-19 will lead us." }\end{array}$ & Neutral \\
\hline $\begin{array}{l}\text { ENGO (environmental } \\
\text { non-governmental } \\
\text { organization) }\end{array}$ & $\begin{array}{l}\text { "I believe Nova Scotians are ready to take the next step. Seven years ago, Superstore } \\
\text { tried to create [a fee] for plastic bags and Nova Scotians were angry. But Walmart had } \\
\text { a similar program three years ago ... and everyone was fine. To me it's demonstrated } \\
\text { a shift in attitude." }\end{array}$ & Support \\
\hline Academic research & $\begin{array}{l}\text { "I think Atlantic Canadians have already expressed their overwhelming support of } \\
\text { such a ban." }\end{array}$ & Support \\
\hline Waste management & "I think it will be well received by the majority of people." & Support \\
\hline
\end{tabular}


Table 3. Cont.

Question: How Do You Predict the General Public Will Respond to a Plastic Bag Ban?

\section{Prince Edward Island ${ }^{1}$}

"A lot of people were really excited, and a lot of people were really annoyed. But it was implemented over a long period of time, there was a lot of notice, and people Support adapted incredibly well."

"I was amazed at how receptive the public were to the plastic bag ban. I thought the

Waste management public would be against it but there weren't any negative comments. It seemed like everyone wanted it to happen."

${ }^{1}$ For Prince Edward Island, the question was adapted to "How did the general public respond to the plastic bag ban?".

Ideally, legislation to address plastic pollution can serve a dual purpose of reducing the targeted item while also encouraging the public to make a conscious effort to reduce their use of other SUPs. Predictions on the potential of a plastic bag ban to reduce the prevalence of other SUPs in society were uncertain. Participants from New Brunswick were largely skeptical, arguing that some SUPs are practically impossible to avoid in today's market, and therefore change is only possible through government intervention. Participants from the other three Atlantic provinces were hopeful, while recognizing the need for further monitoring to confirm effectiveness of SUP reduction policies. Across Atlantic Canada, government workers were the most critical sector, claiming it is too soon to determine public response. ENGO workers, academics, and waste managers were more confident in a reduction in other SUPs, trusting the potential for behavioural change (Table 4).

Table 4. Participant views on potential for a plastic bag ban to reduce societal use of other SUPs.

Question: Do You Think the Plastic Bag Ban Will Also Reduce People's Use of Other Single-Use Plastics Such as Straws, Plastic to-Go Containers or Take Out Coffee Cups?

\begin{tabular}{|c|c|c|}
\hline \multicolumn{3}{|c|}{ New Brunswick } \\
\hline Government & "I'm not sure if there's any evidence to prove that or not right now" & Neutral \\
\hline $\begin{array}{l}\text { ENGO (environmental } \\
\text { non-governmental } \\
\text { organization) }\end{array}$ & $\begin{array}{l}\text { "I think it would start a domino effect. I think that people would start to realize there } \\
\text { are other ways they can reduce their single-use plastic use." }\end{array}$ & Support \\
\hline Academic research & $\begin{array}{l}\text { "Until plastic becomes less convenient than some other material, [society is] going to } \\
\text { keep using it unless the government steps in and says otherwise." }\end{array}$ & Oppose \\
\hline Waste management & $\begin{array}{l}\text { "It helps raise awareness of other single-use plastics. Whether that changes people's } \\
\text { behaviour, we'll have to see" }\end{array}$ & Neutral \\
\hline \multicolumn{3}{|c|}{ Newfoundland and Labrador } \\
\hline $\begin{array}{c}\text { ENGO (environmental } \\
\text { non-governmental } \\
\text { organization) }\end{array}$ & $\begin{array}{l}\text { "To some degree it is starting to change the behaviour ... but there are also those } \\
\text { people who just wait for [government legislation]." }\end{array}$ & Neutral \\
\hline \multicolumn{3}{|c|}{ Nova Scotia } \\
\hline Government & $\begin{array}{l}\text { "It is definitely a way to get people thinking ... and if it's messaged properly then it's } \\
\text { even more likely" }\end{array}$ & Support \\
\hline $\begin{array}{c}\text { ENGO (environmental } \\
\text { non-governmental } \\
\text { organization) }\end{array}$ & $\begin{array}{l}\text { "It could have a positive influence. It will make people think a little more about other } \\
\text { [plastic] products that might not be banned." }\end{array}$ & Support \\
\hline Academic research & $\begin{array}{l}\text { "We see this as a gateway plastic ... so if you reduce plastic bags, it will lead to other } \\
\text { positive reduction in consumer behaviour." }\end{array}$ & Support \\
\hline Waste management & $\begin{array}{l}\text { "I think so because it's become an education piece ... and people are looking at things } \\
\text { differently." }\end{array}$ & Support \\
\hline
\end{tabular}


Table 4. Cont.

\begin{tabular}{|c|c|c|}
\hline \multicolumn{3}{|c|}{$\begin{array}{l}\text { Question: Do You Think the Plastic Bag Ban Will Also Reduce People's Use of Other Single-Use Plastics Such as Straws, } \\
\text { Plastic to-Go Containers or Take Out Coffee Cups? }\end{array}$} \\
\hline \multicolumn{3}{|c|}{ Prince Edward Island ${ }^{1}$} \\
\hline Government & $\begin{array}{l}\text { "There isn't much of an effect, but it is bringing it into the conversation. It might be a } \\
\text { little bit too soon to get a good idea of it." }\end{array}$ & Neutral \\
\hline Waste management & $\begin{array}{l}\text { "Yes, I believe we've seen a big shift. It has definitely had a ripple effect to other } \\
\text { single-use plastics." }\end{array}$ & Support \\
\hline & \multicolumn{2}{|c|}{$\begin{array}{l}{ }^{1} \text { For Prince Edward Island, the question was adapted to "Has the plastic bag ban helped to reduce people's use } \\
\text { of other single-use plastics such as straws, plastic to-go containers or take out coffee cups?". }\end{array}$} \\
\hline & \multicolumn{2}{|c|}{$\begin{array}{l}\text { Identifying single-use plastic issues from experts in the field can provide a direction } \\
\text { for future education and communications materials to the public. Participants from New } \\
\text { Brunswick and Prince Edward Island acknowledged the need for plastic reduction ef- } \\
\text { forts over recycling efforts. Participants in Newfoundland and Labrador and Nova Scotia } \\
\text { discussed self-awareness with plastic use. Across Canada, government workers empha- } \\
\text { sized environmental and socio-economic impacts of plastic pollution on both the natural } \\
\text { and anthropogenic world. ENGOs highlighted the dangers of microplastics. Academics } \\
\text { stressed the importance of accountability for plastic waste produced. Waste managers } \\
\text { called attention to proper waste management and the limitations of the waste stream. } \\
\text { (Table 5). }\end{array}$} \\
\hline
\end{tabular}

Table 5. Single-use plastic tips from interview participants.

\begin{tabular}{|c|c|c|}
\hline \multicolumn{3}{|c|}{ Question: What is Something You Wish People Knew about Single-Use Plastics? } \\
\hline \multicolumn{3}{|c|}{ New Brunswick } \\
\hline Government & "People need to reduce the amount of plastic they produce." & Neutral \\
\hline $\begin{array}{l}\text { ENGO (environmental } \\
\text { non-governmental organization) }\end{array}$ & $\begin{array}{l}\text { "More education and engaging opportunities about microplastics and the effects } \\
\text { of microplastics." }\end{array}$ & Neutral \\
\hline Academic research & $\begin{array}{l}\text { "People think because there's a symbol that says [an item] is recyclable ... that } \\
\text { means they're getting recycled, and that is certainly not true." }\end{array}$ & Neutral \\
\hline Waste management & $\begin{array}{l}\text { "Many people defer and think that the waste industry should find a solution, } \\
\text { when in reality we need to think ... reduction first." }\end{array}$ & Neutral \\
\hline \multicolumn{3}{|c|}{ Newfoundland and Labrador } \\
\hline $\begin{array}{c}\text { ENGO (environmental } \\
\text { non-governmental organization) }\end{array}$ & $\begin{array}{l}\text { "A lot of people overlook that they're throwing something out, but it goes into } \\
\text { the ocean" }\end{array}$ & Neutral \\
\hline \multicolumn{3}{|c|}{ Nova Scotia } \\
\hline Government & $\begin{array}{l}\text { "Plastic fragments in the environment and does not break down for many } \\
\text { thousands of years if not ever." }\end{array}$ & Neutral \\
\hline $\begin{array}{l}\text { ENGO (environmental } \\
\text { non-governmental organization) }\end{array}$ & $\begin{array}{l}\text { "When you litter, no matter where, it is likely going to end up in a waterway, } \\
\text { and then you're going to have microplastics working its way up the food chain." }\end{array}$ & Neutral \\
\hline Academic research & $\begin{array}{l}\text { "If more people were aware of what their actions lead to, then that would } \\
\text { quickly change their habits or would be open to changes in policy." }\end{array}$ & Neutral \\
\hline Waste management & $\begin{array}{l}\text { "A lot of bio and compostable plastic cannot actually be composted in a lot of } \\
\text { municipal recycling centers." }\end{array}$ & Neutral \\
\hline \multicolumn{3}{|c|}{ Prince Edward Island } \\
\hline Government & $\begin{array}{l}\text { "It's not just a litter thing. It's a pollution problem that breaks down right into } \\
\text { our food chain." }\end{array}$ & Neutral \\
\hline Waste management & "Plastic is destructive and takes a long time to degrade." & Neutral \\
\hline
\end{tabular}




\section{Discussion}

There is increasing public interest in government actions on environmental issues due to growing concerns about environmental sustainability and climate change [25]. Skepticism of government-led action on environmental issues is often associated with a lack of involvement, communication, and evidence of success [26]. However, Konisky et al. [27] show that public attitudes on environmental policy differed strongly across issues, with pollution and pollution abatement being strongly supported even by those who identified as being skeptical of other environmental issues [27]. Our survey strongly supports this notion. We found strong public support for government-led action on single-use plastic bags across Atlantic Canada, which corroborates higher regional motivation of consumers to reduce use of SUPs [14-16,18]. For example, Walker et al. [16] reported that most (93.7\%) Canadian respondents, especially residents in Atlantic Canada, were personally motivated to reduce consumption of SUPs food packaging. Equally important, predisposition to recognizing plastic pollution as a problem expectedly translates to a lack of support for government action on a reduction in plastics. This is often the driver for individual proenvironment behaviour [8], or for SUP reduction initiatives by small retailers [15].

We found notable differences in levels of support between whether participants were concerned about the impacts of plastic in the environment or not. Most of those who were concerned about plastic pollution were also supportive of a bag ban, whereas most of those who were not concerned about plastic pollution, or the environment were also unsupportive of a bag ban. This is consistent with other studies who report of individuals who are environmentally conscious (i.e., who already have pro-environmental behaviours) are more likely to support environmental initiatives [14,16,28]. This extreme dichotomy between the two groups is important to consider when planning for future SUP mitigation efforts, especially for targeting education and communication efforts [6,8]. The small minority who expressed a lack of environmental concern could be attributed to a false sense of security or turning a blind eye [29].

At the time of our survey, the government of Prince Edward Island had already implemented a ban on SUP bags under the Plastic Bag Reduction Act on 1 July 2019 [16], which was acknowledged and supported by most survey respondents. After one year of a plastic bag ban, Prince Edward Island has eliminated more than 16 million plastic bags from the waste stream [30], Heather Myers, Disposal Manager, Island Waste Management Corporation, Prince Edward Island, personal communication, 5 March 2020 at the Plastic Packaging Reduction Summit, Dartmouth, Nova Scotia]. However, not all provinces shared the enthusiasm expressed by respondents from Prince Edward Island. For example, lower support was identified for Nova Scotia compared to the other provinces in Atlantic Canada, with semi-structured interviews suggesting this could be a result of poor communication on the then proposed legislative action. The Plastic Bags Reduction Act in Nova Scotia was implemented on 30 October 2020, despite concerns over the COVID-19 pandemic [23]. Currently, each provincial plastic bag ban includes its own exceptions to the legislation, which are not consistent across jurisdictions [31]. Province specific exceptions can create confusion amongst businesses in terms of what is expected of them, and for the public when only certain items are available [15].

Demographic factors were found to be a large contributor to differences in support for legislative action on plastic pollution. Those $<35$ years of age were the most enthusiastic for government-led action on plastic pollution. This is consistent with other studies within Canada [14-16] and elsewhere [32,33]. For example, Reinhart [32] and Ballew et al. [33] noted that those $<35$ years of age are more likely to believe that climate change will pose a serious threat and be the most engaged in climate activism [32,33]. In recent years, there has been a surge in youth-led climate justice movements [34]. Millennials and Gen Zs show a high concern for environmental issues $[15,16]$. Social media has allowed the spread of information faster than ever before, which has created a positive feedback loop where the more attention a movement receives, the more that younger people are drawn to that movement [35]. 
A higher level of education was found to be more supportive of government-led action. Education is often correlated with environmental awareness. Education can lead to the development of new perspectives and moral-based transformations, which encourages a more environmentally conscious mindset [36]. Studies have found that educated individuals have higher levels of environmental concern, and thus are more likely to participate in ecofriendly behaviours $[37,38]$. We also found that females are more likely to be supportive of a plastic bag ban than males. This ideology, termed the "eco gender gap", has already been documented by Mintel [39], who found that in the United Kingdom, 71\% of women are making a conscious effort to live sustainably compared to only $59 \%$ of men. The difference in behaviours may be attributed to disproportionate marketing and/or underlying gender roles [39]. Eco-friendly campaigns and green products are often advertised toward female audience, as if sustainability is "women's work" [40]. The innate mindset of females being the caregiver can create negative stereotypes and further exacerbate the collective effort to become more environmentally sustainable. Additionally, research has found men are less likely to participate in environmentally friendly activities for fear of being perceived as effeminate or to protect their gender identity [41,42]. This includes carrying reusable bags, purchasing green branded products, or even adopting a vegetarian diet [42].

We did not find a clear pattern behind support for government-led initiatives based on employment status; yet our survey does indicate that the least supportive participants are those who are unemployed, followed closely by those who are retired. While age and education may be conflating factors, the lower support among those not in the workforce may also be attributed to the limitation that these individuals are not as exposed to social norms common in the workplace and/or do not have the financial capacity to fund being plastic free. Pro-environmental behaviours within the workplace have been known to influence an individual's attitude towards taking sustainable actions [43]. Additionally, economic costs of transition to a plastic free lifestyle can often be expensive for individuals [16] and retailers [15].

This research was conducted during the COVID-19 global pandemic. As such, it is difficult to determine typical behaviours and perceptions during this time since the use of SUPs increased due to concerns over food safety and because of concerns of virus transmission [44-46]. Prior to the COVID-19 pandemic, Canadian consumers and retailers began to reduce use of SUPs, under the Canada-wide Strategy on Zero Plastic Waste [8,47]. However, to reduce the spread of the virus, many governments around the world implemented precautionary approaches with COVID-19 restrictions and delayed or reversed SUP reduction initiatives [44-46]. In Canada, food services were mandated to close all in-person services, but contactless takeout and delivery was still allowed which resulted in increased use of SUPs, such as Styrofoam containers, plastic cutlery and plastic bags [18].

Data collection occurred during July and August 2020, before the provincial plastic bag bans were implemented in Newfoundland and Labrador, and Nova Scotia. Therefore, responses from these provinces represent participants' anticipated behaviour. Further, most participants in the survey likely already have pro-environmental behaviour which could create bias in the data. There was a disproportionate number of survey respondents with a university level education, increasing the potential for survey results to be positively skewed towards a more environmentally educated mindset. There was also a positive skew toward the representation of females to males; however, this is typical in online surveys in Canada [14,16]. For both the survey and semi-structured interviews, there was an unequal representation between provinces with Nova Scotia and New Brunswick receiving considerably more survey responses than Newfoundland and Labrador and Prince Edward Island. Therefore, it is likely that results from Nova Scotia and New Brunswick are representative of the public consensus on a plastic bag ban.

Although the Canadian government has committed to legislatively ban check-out bags, straws, stir sticks, six-pack rings, plastic cutlery, and food containers made from hard to recycle plastics under Schedule 1 of the Canadian Environmental Protection Act (CEPA) 1999 by the end of 2022 [19-22], this study highlights widespread consumer support for SUP 
reduction legislation in Atlantic Canada. Results from this survey and interviews with key stakeholders, combined with findings from other studies help inform recommendations to support plastic reduction legislation in Atlantic Canada and across Canada more broadly. The following recommendations are also consistent with provincial and federal to reduce use of SUPs, under the Canada-wide Strategy on Zero Plastic Waste [8,48].

1. Fee-to-ban transitions are often referred to as market-based instruments and have been widely adopted in other jurisdictions [7,8,48-50]. Transitions implement a fee on SUP items, which are then subsequently banned [51-54]. Transitions allow for consumer behaviour change for those who are slow to adopt the new legislation. Additionally, implementing a fee would generate revenue which could be used to fund environmental projects, sustainability initiatives and/or subsidies for local businesses to offset cost of zero plastic waste.

2. There is a need to ensure clear communication and to improve public education prior to implementing new legislation. It is especially critical for demographics opposed to these initiatives. Increased awareness will allow the public to better prepare, which also decreases the risk and amount of backlash following implementation, as seen in other jurisdictions around the world [48-54]. There also needs to be clear communication to businesses and retailers so they are aware what is expected of them. We encourage policy makers across Atlantic Canada to increase efforts in communication through education and awareness campaigns to assist in reducing potential for misinformation [18].

3. Improved collaboration needs to be prioritized between all stakeholders. Improving and increasing collaboration, especially among provincial governments could help streamline programs and standardize legislation across Atlantic Canada which would simplify concerns for the public $[14,16,18]$.

4. There is a need for increased pressure on producers to ensure they are being held accountable for their use of plastic in their products by implementing extended producer responsibility (EPR) programs [9]. These are monetary incentive programs that put the management of the product at every stage of its lifecycle on the producer so, ideally, they will make more eco-friendly choices to avoid waste costs. Extended producer responsibility programs can be implemented at both the municipal and regional levels across Canada $[9,47]$.

\section{Conclusions}

Community survey and semi-structured interviews from Atlantic Canada suggest that public perceptions of plastic bag bans are generally positive. Across the four provinces, strong support was expressed for provincial legislative action to ban SUP bags, as well as other forms for SUP mitigation strategies. Gender identity, age, education level, and employment status can all influence individual perspectives of government legislation, with young, educated females being the most supportive demographic. Ultimately, existing concern for the impacts of plastic pollution on the environment is the underlying factor in support for any type of pro-environmental behaviour and SUP reduction actions by individuals. Results of this study highlight target populations for future education and awareness campaigns. Given the current response, future plastic pollution legislation can be anticipated to have greater effectiveness as public acceptance is an indicator of compliance. To improve future plastic pollution legislation, it is recommended that more attention be given to communication efforts for recalcitrant demographics and to strive for the harmonization of legislation across all jurisdictions. Legislation, reduction initiatives, and sustainability efforts are all useful strategies for mitigation the impacts of plastic pollution; however, clear communication of the guidelines and expectations are needed well in advance of implementation to improve public perceptions and acceptability. 
Author Contributions: Conceptualization, S.M., S.J.S., T.R.W. and A.S.M.; methodology, S.M.; software, S.M.; validation, S.M.; formal analysis, S.M.; investigation, S.M.; resources, S.M., S.J.S., T.R.W. and A.S.M.; data curation, S.M.; writing-original draft preparation, S.M.; writing-review and editing, S.M., S.J.S., T.R.W. and A.S.M.; visualization, S.M.; supervision, A.S.M.; project administration, S.M.; funding acquisition, S.J.S. All authors have read and agreed to the published version of the manuscript.

Funding: Funding for research was provided by WWF-Canada, through the Sobey Fund for Oceans.

Institutional Review Board Statement: Not applicable.

Informed Consent Statement: Please add "Informed consent was obtained from all subjects involved in the study". OR "Patient consent was waived due to REASON (please provide a detailed justification)". OR "Not applicable" for studies not involving humans.

Data Availability Statement: Data used in this study will be made publicly available upon request.

Acknowledgments: We express our gratitude to all study participants as well as the three reviewers whose comments helped improve the final version of this paper.

Conflicts of Interest: The authors declare no conflict of interest. The funders had no role in the design of the study; in the collection, analyses, or interpretation of data; in the writing of the manuscript, or in the decision to publish the results.

\section{Appendix A}

Appendix A.1. Survey Questions: A Atlantic Canada Single-Use Plastic Community Survey Questions

Demography

Province:

- New Brunswick

- Newfoundland and Labrador

Nova Scotia

Prince Edward Island

Age:

$18-29$

30-39

$40-49$

50-59

60-69

$70+$

Gender:

Female

Male

Non-Binary

Not listed

Prefer not to say

Highest level of education:

Some high school

High school diploma

Trade school

College diploma

Associates degree

Bachelor's degree

Master's degree

Professional degree

Doctorate degree 
Employment:

Working full-time

- Working part-time

S Self employed

- Student

- Retired

Unemployed

New Brunswick

Are you concerned about the impacts of plastic bags on the environment?

$\bigcirc \quad$ Yes

$\bigcirc \quad$ No

Why?

How often do you see plastic bags in the environment?

Every day

A few times a week

- About once a week

A few times a month

Once a month

$\checkmark$ Less than once a month

How often do you use plastic bags?

Always

Frequently (1-2 times a week)

- Sometimes (1-2 times a month)

Rarely (only when I forget my reusable)

○ Never

How do you dispose of plastic bags?

Garbage

- Recycle

- Reuse plastic bags at home

$\bigcirc$ Other

How many reusable bags do you own?

$\bigcirc \quad$ None

- 1-3

○ $3-5$

○ $6+$

Would you support or oppose a plastic bag ban?

Support

Oppose

Unsure

- No preference

Would a plastic bag ban reduce your use of other single use plastics such as straws, plastic to-go containers or take out coffee cups?

○ Yes

$\circ \quad \mathrm{No}$

Unsure

Would you prefer to pay an additional fee for a plastic bag as opposed to a having plastic bag ban?

$\bigcirc \quad$ Yes 
○ No

Depends on how much the fee was

No preference

Do you think more legislation to reduce plastic pollution should be implemented in your province?

Y Yes

If so, what would you like to see legislation banning?

- No

$\bigcirc \quad$ No preference

Has your use of single-use plastics increased because of Covid-19?

○ Yes

- No

Unsure

Do you have any additional comments about reducing plastic pollution in your province?

\section{Newfoundland and Labrador}

Are you concerned about the impacts of plastic bags on the environment?

Yes

○ No

Why?

How often do you see plastic bags in the environment?

Every day

A few times a week

About once a week

A few times a month

Once a month

Less than once a month

How often do you use plastic bags?

\section{Always}

Frequently (1-2 times a week)

Sometimes (1-2 times a month)

Rarely (only when I forget my reusable)

Never

How do you dispose of plastic bags?

Garbage

Recycle

Reuse plastic bags at home

$\bigcirc$ Other

How many reusable bags do you own?

None

- 1-3

- $3-5$

$6+$

Do you know that a plastic bag ban is coming to force this year?

Yes

○ $\mathrm{No}$

Do you support or oppose the plastic bag ban? 


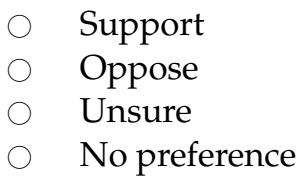

Will the plastic bag ban reduce your use of other single use plastics such as straws, plastic to-go containers or take out coffee cups?
Yes
○ No
$\bigcirc \quad$ Unsure

Would you prefer to pay an additional fee for a plastic bag as opposed to a having plastic bag ban?

$\bigcirc \quad$ Yes

○ No

Depends on how much the fee was

- No preference

Do you think more legislation to reduce plastic pollution should be implemented in your province?

Yes

If so, what would you like to see legislation banning?

$\bigcirc \mathrm{No}$

No preference

Has your use of single-use plastics increased because of Covid-19?

Yes

No

Unsure

Do you have any additional comments about reducing single use plastics or the plastic bag ban in your province?

\section{Nova Scotia}

Are you concerned about the impacts of plastic bags on the environment?

Yes

No

Why?

How often do you see plastic bags in the environment?

Every day

A few times a week

About once a week

A few times a month

Once a month

Less than once a month

How often do you use plastic bags?

Always

Frequently (1-2 times a week)

Sometimes (1-2 times a month)

Rarely (only when I forget my reusable)

Never

How do you dispose of plastic bags?

Garbage 
- Recycle

Reuse plastic bags at home

O Other

How many reusable bags do you own?

None

1-3

3-5

○ $6+$

Do you know that a plastic bag ban is coming to force this year?

Yes

$\bigcirc \quad$ No

Do you support or oppose the plastic bag ban?

\section{Support}

Oppose

Unsure

No preference

Will the plastic bag ban reduce your use of other single use plastics such as straws, plastic to-go containers or take out coffee cups?

$\bigcirc \quad$ Yes

- No

Unsure

Would you prefer to pay an additional fee for a plastic bag as opposed to a having plastic bag ban?

Yes

No

Depends on how much the fee was

No preference

Do you think more legislation to reduce plastic pollution should be implemented in your province?

$\bigcirc \quad$ Yes

If so, what would you like to see legislation banning?

- No

$\bigcirc \quad$ No preference

Has your use of single-use plastics increased because of Covid-19?

$\bigcirc \quad$ Yes

- No

$\bigcirc \quad$ Unsure

Do you have any additional comments about reducing single use plastics or the plastic bag ban in your province?

\section{Prince Edward Island}

Are you concerned about the impacts of plastic bags on the environment?

$\bigcirc \quad$ Yes

$\circ \quad \mathrm{No}$

Why?

How often do you see plastic bags in the environment?

Every day 
A few times a week

About once a week

A few times a month

Once a month

Less than once a month

How do you dispose of old plastic bags?

Garbage

Recycle

Reuse plastic bags at home

Other

How many reusable bags do you own?

None

- $1-3$

○ $3-5$

○ $6+$

Do you support or oppose the current plastic bag ban?

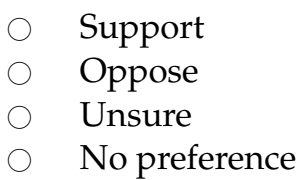

Has the plastic bag ban reduced your use of other single use plastics such as straws, plastic to-go containers or take out coffee cups?

Y Yes

- No

Unsure

Would you prefer to pay an additional fee for a plastic bag as opposed to a having plastic bag ban?

Yes

No

Depends on how much the fee was

No preference

Do you think more legislation to reduce plastic pollution should be implemented in your province?

$\bigcirc \quad$ Yes

If so, what would you like to see legislation banning?

No

No preference

Has your use of single-use plastics increased because of Covid-19?

Y Yes

○o

$\bigcirc \quad$ Unsure

Do you have any additional comments about reducing single use plastics or the plastic bag ban in your province?

Appendix A.2. Semi-Structured Interview Questions: Atlantic Canada Single-Use Plastic Semi-structured Interview Questions

New Brunswick (8 questions)

How does your work relate to single use plastics? 
What is your reaction to the recent announcement by the Canadian Federal Government to ban single use plastics as soon as 2021?

Have you noticed a change in the amount of plastic pollution in your province over the last 5 years?

Do you think New Brunswick should implement a plastic bag ban?

Do you think a plastic bag ban would also reduce people's use of other single use plastics such as straws, plastic to-go containers or take out coffee cups?

Do you think more legislation to reduce plastic pollution should be implemented in your province? If so, what would you like to see legislation banning?

What is something you wish people knew about single use plastics?

Do you have any other comments about reducing single use plastics or the plastic bag ban in your province?

Newfoundland and Labrador (8 questions)

How does your work relate to single use plastics?

What is your reaction to the recent announcement by the Canadian Federal Government to ban single use plastics as soon as 2021?

Have you noticed a change in the amount of plastic pollution in your province over the last 5 years?

How do you think the general public will respond to the upcoming plastic bag ban? And do you have any ideas on how to make sure implementation is successful?

Do you think the plastic bag ban will also reduce people's use of other single use plastics such as straws, plastic to-go containers or take out coffee cups?

Do you think more legislation to reduce plastic pollution should be implemented in your province? If so, what would you like to see legislation banning?

What is something you wish more people knew about single use plastics?

Do you have any other comments about reducing single use plastics or the plastic bag ban in your province?

Nova Scotia (8 questions)

How does your work relate to single use plastics?

What is your reaction to the recent announcement by the Canadian Federal Government to ban single use plastics as soon as 2021?

Have you noticed a change in the amount of plastic pollution in your province over the last 5 years?

How do you think the general public will respond to the upcoming plastic bag ban? And do you have any ideas on how to make sure implementation is successful?

Do you think the plastic bag ban will also reduce people's use of other single use plastics such as straws, plastic to-go containers or take out coffee cups?

Do you think more legislation to reduce plastic pollution should be implemented in your province? If so, what would you like to see legislation banning?

What is something you wish people knew about single use plastics?

Do you have any other comments about reducing single use plastics or the plastic bag ban in your province?

Prince Edward Island (8 questions)

How does your work relate to single use plastics?

What is your reaction to the recent announcement by the Canadian Federal Government to ban single use plastics as soon as 2021?

Have you noticed a change in the amount of plastic pollution now that the plastic bag ban has been implemented?

How did the general public responded to the plastic bag ban? And do you have any ideas on how implementation might have been improved?

Has the plastic bag ban helped to reduce people's use of other single use plastics such as straws, plastic to-go containers or take out coffee cups?

Do you think more legislation to reduce plastic pollution should be implemented in your province? If so, what would you like to see legislation banning? 
What is something you wish people knew about single use plastics?

Do you have any other comments about reducing single use plastics or the plastic bag ban in your province?

Table A1. ANOVA Results from the Community Survey.

\begin{tabular}{|c|c|c|c|}
\hline \multicolumn{4}{|c|}{ ATLANTIC CANADA } \\
\hline & $\mathrm{F}$ & Fcrit & $\mathrm{p}$-value \\
\hline Location & 8.25025268 & 6.59138212 & 0.03456333 \\
\hline Age & 3.64257409 & 4.38737419 & 0.07345149 \\
\hline Gender & 1.89575499 & 18.5128205 & 0.30241797 \\
\hline Education & 0.95901713 & 3.22958261 & 0.51811784 \\
\hline Employment & 2.52591393 & 4.38737419 & 0.14517506 \\
\hline Concern & 1.04784524 & 18.5128205 & 0.4136565 \\
\hline \multicolumn{4}{|c|}{ NEW BRUNSWICK } \\
\hline & $\mathrm{F}$ & Fcrit & $\mathrm{p}$-value \\
\hline Age & 0.42141072 & 4.38737419 & 0.81931985 \\
\hline Gender & 4.06083563 & 18.5128205 & 0.18145709 \\
\hline Education & 0.79554457 & 3.22958261 & 0.62114344 \\
\hline Employment & 1.45261757 & 4.38737419 & 0.32840982 \\
\hline Concern & 0.87082641 & 18.5128205 & 0.44924008 \\
\hline \multicolumn{4}{|c|}{ NEWFOUNDLAND AND LABRADOR } \\
\hline & $\mathrm{F}$ & Fcrit & $\mathrm{p}$-value \\
\hline Age & 1.00573635 & 4.38737419 & 0.48688875 \\
\hline Gender & 0.58346482 & 18.5128205 & 0.52476758 \\
\hline Education & 15.8571429 & 3.50046386 & 0.00041745 \\
\hline Employment & 0.73352776 & 4.38737419 & 0.62442612 \\
\hline Concern & 0.83818232 & 18.5128205 & 0.45656313 \\
\hline \multicolumn{4}{|c|}{ NOVA SCOTIA } \\
\hline & $\mathrm{F}$ & Fcrit & $\mathrm{p}$-value \\
\hline Age & 3.09081811 & 4.38737419 & 0.10101752 \\
\hline Gender & 0.99430545 & 18.5128205 & 0.42374878 \\
\hline Education & 0.80816033 & 3.22958261 & 0.61271856 \\
\hline Employment & 1.3587749 & 4.38737419 & 0.35586173 \\
\hline Concern & 0.89091959 & 18.5128205 & 0.44486163 \\
\hline \multicolumn{4}{|c|}{ PRINCE EDWARD ISLAND } \\
\hline & $\mathrm{F}$ & Fcrit & $\mathrm{p}$-value \\
\hline Age & 11.4816327 & 4.38737419 & 0.00497962 \\
\hline Gender & 0.00469131 & 18.5128205 & 0.95162473 \\
\hline Education & 0.56533921 & 3.86596885 & 0.74785466 \\
\hline Employment & 12.2454281 & 4.38737419 & 0.00420544 \\
\hline Concern & 3.64341394 & 18.5128205 & 0.19650477 \\
\hline
\end{tabular}


Table A2. Tukey-Kramer Post Hoc Test results from statistically significant categories within the community survey.

\begin{tabular}{|c|c|c|}
\hline \multicolumn{3}{|c|}{ ATLANTIC CANADA-Location } \\
\hline Comparison & Absolute Mean Diff & Qcrit \\
\hline New Brunswick vs. Nova Scotia & 11.19065859 & 6.870884196 \\
\hline Newfoundland and Labrador vs. Nova Scotia & 10.60163013 & 6.870884196 \\
\hline Prince Edward Island vs. Nova Scotia & 11.54239019 & 6.870884196 \\
\hline \multicolumn{3}{|c|}{ NEWFOUNDLAND AND LABRADOR_Education } \\
\hline Comparison & Absolute Mean Diff & Qcrit \\
\hline High school vs. trade school & 25 & 10.368249 \\
\hline College vs. trade school & 33.33333333 & 10.368249 \\
\hline Bachelor's degree vs. trade school & 33.33333333 & 10.368249 \\
\hline Master's degree vs. trade school & 33.33333333 & 10.368249 \\
\hline Professional degree vs. trade school & 33.33333333 & 10.368249 \\
\hline Doctorate degree vs. trade school & 33.33333333 & 10.368249 \\
\hline \multicolumn{3}{|c|}{ PRINCE EDWARD ISLAND—Age } \\
\hline Comparison & Absolute Mean Diff & Qcrit \\
\hline $18-24$ vs. $45-54$ & 9.523809524 & 5.776388889 \\
\hline $25-34$ vs. $45-54$ & 9.523809524 & 5.776388889 \\
\hline $35-44$ vs. $45-54$ & 9.523809524 & 5.776388889 \\
\hline $55-64$ vs. $45-54$ & 9.523809524 & 5.776388889 \\
\hline $18-24$ vs. $65+$ & 12.5 & 5.776388889 \\
\hline $25-34$ vs. $65+$ & 12.5 & 5.776388889 \\
\hline $35-44$ vs. $65+$ & 12.5 & 5.776388889 \\
\hline 55-64 vs. $65+$ & 12.5 & 5.776388889 \\
\hline \multicolumn{3}{|c|}{ PRINCE EDWARD ISLAND—Employment } \\
\hline Comparison & Absolute Mean Diff & Qcrit \\
\hline Working full-time vs. self-employed & 10.11904762 & 5.242247273 \\
\hline Working full time vs. retired & 6.442577031 & 5.242247273 \\
\hline Working part time vs. self-employed & 12.5 & 5.242247273 \\
\hline Working part time vs. retired & 8.823529412 & 5.242247273 \\
\hline Student vs. self-employed & 12.5 & 5.242247273 \\
\hline Student vs. retired & 8.823529412 & 5.242247273 \\
\hline Retired vs. unemployed & 8.823529412 & 5.242247273 \\
\hline Self-employed vs. unemployed & 12.5 & 5.242247273 \\
\hline
\end{tabular}

\section{References}

1. Davis, H. Life and Death in the Anthropocene: A Short History of Plastic. In Art in the Anthropocene: Encounters among Aesthetics, Politics, Environments and Epistemologies; Open Humanities Press: London, UK, 2015; pp. 347-358.

2. Beaumont, N.; Aanesen, M.; Austen, M.; Börger, T.; Clark, J.; Cole, M.; Hooper, T.; Lindeque, P.; Pascoe, C.; Wyles, K. Global ecological, social and economic impacts of marine plastic. Mar. Pollut. Bull. 2019, 142, 189-195. [CrossRef] [PubMed] 
3. Andrady, A.; Neal, M. Applications and Societal Benefits of Plastics. Philos. Trans. R. Soc. B Biol. Sci. 2009, 364, 1977-1984. [CrossRef] [PubMed]

4. Geyer, R.; Jambeck, J.; Lavender-Law, K. Production, use, and fate of all plastics ever made. Sci. Adv. 2017, 3, e1700782. [CrossRef] [PubMed]

5. Borrelle, S.; Ringma, J.; Law, K.L.; Monnahan, C.; Lebreton, L.; McGivern, A.; Murphy, E.; Jambeck, J.; Leonard, G.H.; Hilleary, M.A.; et al. Predicted growth in plastic waste exceeds efforts to mitigate plastic pollution. Science 2020, 369, 1515-1518. [CrossRef] [PubMed]

6. Pettipas, S.; Bernier, M.; Walker, T.R. A Canadian policy framework to mitigate plastic marine pollution. Mar. Policy 2016, 68, 117-122. [CrossRef]

7. Xanthos, D.; Walker, T.R. International policies to reduce plastic marine pollution from single-use plastics (plastics bags and microbeads): A review. Mar. Pollut. Bull. 2017, 118, 17-26. [CrossRef]

8. Schnurr, R.; Alboiu, V.; Chaudhary, M.; Corbett, R.; Quanz, M.; Sankar, K.; Srain, H.; Thavarajah, V.; Xanthos, D.; Walker, T.R Reducing marine pollution from single-use plastics (SUPs): A review. Mar. Pollut. Bull. 2018, 137, 157-171. [CrossRef]

9. Diggle, A.; Walker, T.R. Implementation of harmonized Extended Producer Responsibility strategies to incentivize recovery of single-use plastic packaging waste in Canada. Waste Manag. 2020, 110, 20-23. [CrossRef]

10. Inglehart, R. Public Support for Environmental Protection: Objective Problems and Subjective values in 43 Societies. Polit. Sci. Polit. 1995, 28, 57-72. [CrossRef]

11. Fairbrother, M. Trust and Public Support for Environmental Protection in Diverse National Contexts. Sociol. Sci. 2016, 3, 359-382. [CrossRef]

12. Deloitte. Economic Study of the Canadian Plastic Industry, Markets, and Waste; Environment and Climate Change Canada: Québec, QC, Canada, 2019. Available online: http:/ / publications.gc.ca/collections/collection_2019/eccc/En4-366-1-2019-eng.pdf (accessed on 13 June 2021).

13. Government of Canada. Industry Profile for the Canadian Plastic Products Industry. 2017. Available online: https://www.ic.gc. ca/eic/site/plastics-plastiques.nsf/eng/p101383.html (accessed on 13 June 2021).

14. Kitz, R.; Walker, T.R.; Charlebois, S.; Music, J. Food packaging during the COVID-19 pandemic: Consumer perceptions. Int. J. Consum. Stud. 2021, 1-15. [CrossRef] [PubMed]

15. Varkey, P.; Walker, T.R.; Saunders, S. Identifying barriers to reducing single-use plastic use in a coastal metropolitan city in Canada. Ocean Coast. Manag. 2021, 210, 105663. [CrossRef]

16. Walker, T.R.; McGuinty, E.; Charlebois, S.; Music, J. Single-use plastic packaging in Canadian food industry: Consumer behaviour and perceptions. Humanit. Soc. Sci. Commun. 2021, 8, 80. [CrossRef]

17. Charlebios, S.; Walker, T.R.; Music, J. Comment on the food industry's pandemic packaging. Front. Sustain. $2022,3,812608$. [CrossRef]

18. Molloy, S.; Varkey, P.; Walker, T.R. Investigating Opportunities for Single-Use Plastic Reduction in the Food Service Sector during COVID-19. 2022. Available online: https://divertns.ca/sites/default/files/researchreportsfiles/2021-12/SUP\%20Reduction \%20in\%20Food\%20Services_1.pdf (accessed on 13 June 2021).

19. Environment and Climate Change Canada. Canada One-Step Closer to Zero Plastic Waste by 2030. 2020. Available online: https:/ / www.canada.ca/en/environment-climate-change/news/2020/10/canada-one-step-closer-to-zero-plastic-wast e-by-2030.html (accessed on 13 June 2021).

20. Justin Trudeau-Prime Minister of Canada. Canada to Ban Harmful Single-Use Plastics and Hold Companies Responsible for Plastic Waste. 2019. Available online: https:/ / pm.gc.ca/en/news/news-releases/2019/06/10/canada-ban-harmful-single-useplastics-and-hold-companies-responsible (accessed on 13 June 2021).

21. Environment and Climate Change Canada. Discussion Paper: A Proposed Integrated Management Approach to Plastic Products to Prevent Waste and Pollution. 2020. Available online: https://www.canada.ca/content/dam/eccc/documents/pdf/cepa/pr oposed-approach-plastic-management-eng.pdf (accessed on 13 June 2021).

22. Walker, T.R. Plastic industry plan to sue the Canadian federal government for listing plastic as toxic may increase plastic marine pollution. Mar. Pollut. Bull. 2021, 169, 112583. [CrossRef]

23. Government of Nova Scotia. Bill 152 Plastic Bags Reduction Act. 2019. Available online: https://nslegislature.ca/legc/bills/63rd _2nd/1st_read/b152.htm (accessed on 13 June 2021).

24. Maguire, M.; Delahunt, B. Doing a Thematic Analysis: A Practical, Step-by-Step Guide for Learning and Teaching Scholars. All Irel. J. Teach. Learn. High. Educ. 2017, 3, 335.

25. Johnson, R.J.; Scicchitano, M.J. Uncertainty, risk, trust, and information: Public perceptions of environmental issues and willingness to take action. Policy Stud. J. 2000, 28, 633-647. [CrossRef]

26. Burby, R.J. Making plans that matter: Citizen involvement and government action. J. Am. Plan. Assoc. 2007, 69, 33-49. [CrossRef]

27. Konisky, D.M.; Milyo, J.; Richardson, L.E. Environmental policy attitudes: Issues, geographical scale, and political trust. Soc. Sci. Q. 2008, 89, 1066-1085. [CrossRef]

28. Yusliza, M.; Amirudin, A.; Rahadi, R.; Athirah, N.; Ramayah, T.; Muhammad, Z.; Dal Mas, F.; Massaro, M.; Saputra, J.; Mokhlis, S. An Investigation of Pro-Environmental Behaviour and Sustainable Development in Malaysia. Sustainability 2020, $12,7083$. [CrossRef] 
29. Thomas, L. How and Why Environmental Issues are Neglected. 2013. Available online: https://environment-review.yale.edu/ how-and-why-environmental-issues-are-neglected-0 (accessed on 13 June 2021).

30. Van Kampen, S. Single-Use Plastic Bags all but Disappear from P.E.I.'s Waste System in 1st Year of Ban. 2020. Available online: https://www.cbc.ca/news/canada/prince-edward-island/single-use-plastic-bag-ban-pei-1.5632650 (accessed on 13 June 2021).

31. Molloy, S. Action Goals of the Single Use Plastic Working Group; WWF-Canada: Toronto, ON, Canada, 2020 ; pp. 1-33.

32. Reinhart, R. Global Warming Age Gap: Younger Americans Most Worried. 2018. Available online: https://news.gallup.com/poll /234314/global-warming-age-gap-younger-americans-worried.aspx (accessed on 11 May 2018).

33. Ballew, M.; Marlon, J.; Rosenthal, S.; Gustafson, A.; Kotcher, J.; Maibach, E.; Leiserowitz, A. Do Younger Generations Care More About Global Warming? 2019. Available online: https://climatecommunication.yale.edu/publications/do-younger-generationscare-more-about-global-warming/ (accessed on 11 June 2019).

34. United Nations. Youth and Climate Change. 2013. Available online: https://www.un.org/esa/socdev/documents/youth/fact-s heets/youth-climatechange.pdf (accessed on 13 June 2021).

35. Marris, E. Why young climate activists have captured the world's attention. Nature 2019, 573, 471-472. [CrossRef]

36. Simsekli, Y. An Implementation to Raise Environmental Awareness of Elementary Education Students. Procedia-Soc. Behav. Sci. 2015, 191, 222-226. [CrossRef]

37. Hoffmann, R.; Muttarak, R. Greening through schooling: Understanding the link between education and pro-environmental behavior in the Philippines. Environ. Res. Lett. 2019, 15, 014009. [CrossRef]

38. Meyer, A. Does education increase pro-environmental behavior? Evidence from Europe. Ecol. Econ. 2015, 116, 108-121. [CrossRef]

39. Anshelm, J.; Hultman, M. A green fatwā? Climate change as a threat to the masculinity of industrial modernity. NORMA Int. J. Masc. Stud. 2014, 9, 84-96. [CrossRef]

40. Brough, A.; Wilkie, J.; Ma, J.; Isaac, M.; Gal, D. Is Eco-Friendly Unmanly? The Green-Feminine Stereotype and Its Effect on Sustainable Consumption. J. Consum. Res. 2016, 43, 567-582. [CrossRef]

41. Swim, J.; Gillis, A.; Hamaty, K. Gender Bending and Gender Conformity: The Social Consequences of Engaging in Feminine and Masculine Pro-Environmental Behaviors. Sex Roles 2020, 82, 363-385. [CrossRef]

42. Räty, R.; Carlsson-Kanyama, A. Energy consumption by gender in some European countries. Energy Policy 2010, 38, 646-649. [CrossRef]

43. Banwo, A.; Du, J. Workplace pro-environmental behaviors in small and medium-sized enterprises: An employee level analysis. J. Glob. Entrep. Res. 2019, 9, 34. [CrossRef]

44. Prata, J.C.; Silva, A.L.; Walker, T.R.; Duarte, A.C.; Rocha-Santos, T. COVID-19 pandemic repercussions on the use and management of plastics. Environ. Sci. Technol. 2020, 54, 7760-7765. [CrossRef]

45. Silva, A.L.P.; Prata, J.C.; Walker, T.R.; Campos, D.; Duarte, A.C.; Soares, A.M.; Barcelò, D.; Rocha-Santos, T. Rethinking and optimising plastic waste management under COVID-19 pandemic: Policy solutions based on redesign and reduction of single-use plastics and personal protective equipment. Sci. Total Environ. 2020, 742, 140565. [CrossRef]

46. Silva, A.L.P.; Prata, J.C.; Walker, T.R.; Duarte, A.C.; Ouyang, W.; Barcelò, D.; Rocha-Santos, T. Increased plastic pollution due to COVID-19 pandemic: Challenges and recommendations. Chem. Eng. J. 2021, 405, 126683. [CrossRef] [PubMed]

47. Walker, T.R.; Xanthos, D. A call for Canada to move toward zero plastic waste by reducing and recycling single-use plastics. Resour. Conserv. Recycl. 2018, 133, 99-100. [CrossRef]

48. Adam, I.; Walker, T.R.; Bezerra, J.C.; Clayton, A. Policies to reduce single-use plastic marine pollution in West Africa. Mar. Policy 2020, 116, 103928. [CrossRef]

49. Bezerra, J.C.; Walker, T.R.; Clayton, C.A.; Adam, I. Single-use plastic bag policies in the Southern African development community. Environ. Chall. 2021, 3, 100029. [CrossRef]

50. Clayton, C.A.; Walker, T.R.; Bezerra, J.C.; Adam, I. Policy responses to reduce single-use plastic marine pollution in the Caribbean. Mar. Pollut. Bull. 2021, 162, 111833. [CrossRef]

51. Knoblauch, D.; Mederake, L.; Stein, U. Developing countries in the lead-What drives the diffusion of plastic bag policies? Sustainability 2018, 10, 1994. [CrossRef]

52. Nielsen, T.D.; Holmberg, K.; Stripple, J. Need a bag? A review of public policies on plastic carrier bags-Where, how and to what effect? Waste Manag. 2019, 87, 428-440. [CrossRef]

53. Cristi, M.A.; Holzapfel, C.; Nehls, M.; De Veer, D.; Gonzalez, C.; Holtmann, G.; Honorato-Zimmer, D.; Kiessling, T.; Leyton Muñoz, A.; Narváez Reyes, S.; et al. The rise and demise of plastic shopping bags in Chile--Broad and informal coalition supporting ban as a first step to reduce single-use plastics. Ocean Coast. Manag. 2020, 187, 105079. [CrossRef]

54. Zambrano-Monserrate, M.A.; Ruano, M.A. Do you need a bag? Analyzing the consumption behavior of plastic bags of households in Ecuador. Resour. Conserv. Recycl. 2020, 152, 104489. [CrossRef] 